\title{
Sombreamento com iluminação: desenvolvimento e teste de modelo paramétrico para facilitar o projeto de proteções solares
}

\author{
Shading with daylight: development and testing of a \\ parametric model to facilitate design choices of shading \\ devices
}

\begin{abstract}
Raoni Venâncio
Resumo

$\mathbf{E}$ ste artigo tem o objetivo de desenvolver e testar um modelo paramétrico para ser utilizado em fases iniciais do projeto de proteções solares. Com o uso de avaliação multicritério, a ferramenta busca otimizar soluções para atender a objetivos aparentemente conflitantes: obstrução da radiação solar e aproveitamento de iluminação natural. O modelo geométrico consiste em ambiente com uma janela e possibilidade de configuração de uma obstrução externa. Ao todo, quatro tipos de proteções solares podem ser selecionados e configurados. Foram definidos três objetivos de desempenho para avaliação multicritério com algoritmos genéticos: maximizar a quantidade de pontos entre 300 e 750 lux, reduzir a incidência anual de radiação na superfície de abertura e aumentar a iluminância média. Na primeira etapa, foram calculadas 35 gerações de casos, cada geração com 100 indivíduos. Os resultados de simulação são plotados em gráfico $3 \mathrm{~d}$ cujos eixos representam os objetivos. Assim, áreas diferentes do gráfico têm comportamentos distintos de desempenho e tendem a apresentar soluções variadas. A partir da posição no gráfico, foram selecionados seis casos para simulação anual. Os resultados indicam que, no cenário simulado com abertura voltada para oeste, há convergência entre os objetivos de iluminação e sombreamento: quanto menor a incidência de radiação solar, maior a porcentagem média de horas entre 100 e 2.000 lux e entre 300 e 750 lux.
\end{abstract}

Palavras-chave: Projeto generativo. Sombreamento. Iluminação. Avaliação multicritério.

\begin{abstract}
This study aims to develop and test a parametric model to be used in the early design stages of shading devices. With the adoption of multi-criteria analysis, the tool seeks to optimize solutions in order to meet criteria that are apparently conflicting: blocking solar radiation and providing the incidence of daylight. The geometric model consists of a room with one window and also the possibility of an external obstacle. Four types of shading devices can be selected and adjusted by users. Three performance objectives were defined for multicriteria evaluation with genetic algorithms: to maximise the number of points between 300 and 750 lux, to reduce the incidence of direct solar radiation on the window surface, and to increase average illuminance levels. In the first stage, 35 generations of cases, each with 100 individuals, were calculated. The simulation results are plotted in a three-dimensional graph that has an axis for each performance goal. Therefore, different areas of this graph have different performance features and, consequently, varied solutions. Based on their relative position on the graph, six cases were selected to be further investigated with annual daylight simulation. The results indicate that, in the simulated scenario with a generous window facing west, there is convergence between the lighting and shading objectives: the lower the incidence of solar radiation, the higher the average percentage of hours between 100 and 2000lux and between 300 and 750 lux.
\end{abstract}

Keywords: Generative design. Sun shading. Daylight. Multi-criteria analysis. 


\section{Introdução}

Neste artigo são descritos os processos de desenvolvimento e teste de uma ferramenta paramétrica que pode auxiliar no projeto de proteções solares. Os elementos de sombreamento devem obstruir a radiação solar direta - minimizando ganhos térmicos no ambiente - e, ainda assim, permitir a incidência da luz natural no ambiente.

Lidar com as necessidades de sombrear e iluminar associadas ao uso de proteção solar é um processo complexo, pois ambos os critérios são interligados. Como grande parte das decisões de um projeto, o problema pode ser abordado de modo qualitativo ou quantitativo.

Mesmo quando o processo decisório envolve objetivos mensuráveis de desempenho, a apreciação sobre questões de projeto pode se embasar em conhecimentos de natureza qualitativa. Tais fontes de informação podem ser derivadas de resultados de pesquisas científicas, de experiências prévias do arquiteto, ser baseadas em analogias a exemplos existentes, dentre outros tipos de mecanismos heurísticos descritos por Bay (2001).

Dentre as possibilidades de abordagem qualitativa, o uso de princípios ou diretrizes gerais de projeto pode embasar decisões iniciais de projeto. Essas recomendações de projeto são apresentadas de forma acessível ao projetista comum, mesmo que tenham consistente base científica (PEDRINI, 2003). Há princípios gerais que podem ser seguidos quando fazemos o projeto de uma proteção solar para maximizar a exposição a certas áreas do céu enquanto se obstrui a radiação solar direta. Avaliações de máscara de sombra na carta solar são úteis nesse sentido, pois ajudam a visualizar as áreas sombreadas e expostas da abóboda celeste.

O manual elaborado por O'Connor et al. (1997) em forma de livro exemplifica, de forma didática e fartamente ilustrada, grande parte das boas práticas de projeto para maximizar a incidência de luz natural. Vale ressaltar, contudo, que, ainda que esse conhecimento seja válido para minimizar a chance de erro, é pouco provável que resultem em soluções de alto desempenho. Essa limitação ocorre não somente porque as recomendações, de caráter generalista, não representam totalmente as especificidades de uma situação real de projeto, mas porque não permitem a comparação entre soluções diferentes - pré-requisito básico para se buscar maior desempenho.

Logo, se aspectos de desempenho são prioritários no projeto, há necessidade de estudos comparativos entre determinado grupo de soluções viáveis baseados em dados quantitativos. Entretanto, além da complexidade inerente a esses procedimentos de simulação, a compreensão de que processos de avaliação de desempenho devem permear todo o processo de projeto é limitada na prática de projeto. A realização de processos de simulação é mais comum em etapas finais do processo de projeto com o intuito de permitir uma confirmação de desempenho (DE WILDE, 2004), o que restringe o uso desses procedimentos para efetivamente auxiliar na tomada de decisões.

Considerando a maior margem de erro associada ao suporte qualitativo das decisões de projeto e a maior complexidade de procedimentos de simulação da edificação, o desenvolvimento de ferramentas computacionais destinadas a fases iniciais de projeto pode ser eficaz para auxiliar definições influentes nas primeiras fases do processo de concepção (PEDRINI, 2003). De certo modo, são ferramentas que buscam combinar a capacidade do computador em processar cálculos complexos com a facilidade de uso da ferramenta, o que só é possível com algum nível de simplificação do modelo - necessário para simulações computacionais em fases iniciais de projeto, quando muitas das decisões ainda não foram tomadas pelo projetista (VENÂNCIO, 2012).

Nesse contexto, a popularização de interfaces de programação visual tem tido grande influência no desenvolvimento de novas ferramentas de apoio ao projeto. O Grasshopper, principal ferramenta open source de modelagem paramétrica, agrega uma comunidade mundial significativa que colabora ativamente com a criação de plugins para realizar diversos tipos de simulação. No programa, o modelo é criado a partir da combinação de componentes e parâmetros, representados por caixas com conectores para inputs e outputs. As diversas conexões entre componentes podem representar comandos e regras que possibilitam a automatização de processos de modelagem ou desenho geométrico no programa Rhino3d.

Com o uso de modelos paramétricos e plugins que aplicam algoritmos que simulam a evolução das espécies (projeto generativo), pode-se configurar as manipulações do modelo para a obtenção de soluções que atendem a determinado(s) objetivo(s) de desempenho.

Com o intuito de colaborar com uma ferramenta computacional de suporte ao projeto, este artigo tem o objetivo de desenvolver e testar modelo paramétrico que possa ser utilizado como ferramenta de simulação 
para o projeto de proteções solares para a otimização de sombreamento e iluminação natural com o uso do software Grasshopper e de plugins para simulações (LadyBug e HoneyBee) e projeto generativo (Galapagos e Octopus).

\section{Referencial teórico}

A elaboração do modelo paramétrico requer compreensão sobre os aspectos e as grandezas a serem investigados através de simulação computacional e entendimento sobre o processo de otimização de soluções que aplicam algoritmos de projeto generativo. Essa fundamentação teórica fornece suporte para as definições dos tipos de cálculos que devem ser incorporados no modelo e também auxiliam na configuração dos algoritmos que simulam a evolução das soluções e interpretação dos resultados obtidos.

\section{Grandezas e avaliações da iluminação natural}

Ferramentas de simulação de grandezas relacionadas à incidência de iluminação natural vêm sendo aperfeiçoadas nas últimas décadas. Esse processo de evolução também foi acompanhado por debate acerca dos parâmetros quantitativos mais pertinentes para descreverem o comportamento da iluminação natural.

Os resultados de simulações computacionais podem ser divididos em duas categorias principais: avaliações estáticas e dinâmicas.

Simulações estáticas da iluminação natural são realizadas em determinada condição de céu fixa, que pode ser associada a uma data e horário específicos. A grandeza mais usada durante o século XX é o fator de luz diurna (FLD), cujos conceitos foram formulados em 1909 e aperfeiçoados a partir da década de 40 (REINHART; MARDALJEVIC; ROGERS, 2006). O FLD representa uma porcentagem da luz de todo o céu em determinado ponto no interior da edificação. Tradicionalmente, essa avaliação adota o céu encoberto da CIE, que apresenta maiores luminâncias próximas ao zênite e uma redução gradativa até o horizonte independentemente da posição do sol.

Apesar das limitações evidentes, o cálculo do FLD é o método quantitativo mais amplamente usado e aceito até pouco tempo atrás (REINHART; MARDALJEVIC; ROGERS, 2006). Porém, enquanto grandeza a ser usada no projeto, o FLD é um parâmetro quantitativo unidimensional. Em tese, quanto maior o valor obtido, melhor seria o desempenho. Consequentemente, soluções com maior área de abertura e janelas com maior altura deveriam ser priorizadas. Por desconsiderar a influência da radiação direta e posição do sol, essas alternativas aumentariam significativamente a chance de ofuscamento e incidência de radiação direta, comprometendo não somente a qualidade da iluminação, mas o desempenho térmico da edificação.

A simulação estática de iluminâncias internas supre algumas das deficiências do FLD com cálculos relativamente rápidos. O desenvolvimento de métodos de caracterização do céu com base em dados climáticos (MARDALJEVIC, 2006) faz com que o cenário simulado seja mais realista do que os céus genéricos usados para calcular o FLD. Todavia, o problema reside na natureza estática desse tipo de avaliação. Cada simulação realizada representa determinada hora do ano. Como sabemos que a iluminação natural sofre oscilações significativas de acordo com o clima e ao longo do dia, não há como mensurar as variações anuais de iluminação com esse tipo de cálculo. Logo, deve-se selecionar e simular determinados cenários extremos para ter alguma noção sobre essas variações, o que dificulta os procedimentos de análise de resultados. Ademais, não há método claro que permita definir esses cenários de modo inequívoco.

A predição de grandezas de iluminação a partir de dados climáticos abre possibilidade para o desenvolvimento de métricas dinâmicas para iluminação natural (MARDALJEVIC, 2006). Como a caracterização do céu está vinculada aos dados de um arquivo climático, seria possível realizar uma simulação de iluminação de todas as horas em que a edificação é ocupada e compilar esses dados num resultado unificado.

A grandeza daylight autonomy (DA) (autonomia de luz diurna) foi concebida para lidar com as variações de iluminância no plano de trabalho ao longo de determinado período (normalmente um ciclo de um ano). Por definição, a DA consiste na porcentagem de horas que um valor alvo de iluminância é atingido com luz natural. Esses limites mínimos são definidos com base na norma aplicável e vigente, que no caso brasileiro é a ABNT (2013). Ainda que se possa fornecer uma estimativa da distribuição de luz natural no interior do ambiente ao longo do ano através do cálculo de DA, a grandeza só leva em conta o alvo de iluminância. Como consequência, na falta de um limite máximo, não há preocupação com excesso de iluminação associado à incidência de radiação direta nos ambientes. 
Para resolver algumas das limitações, o conceito de useful daylight iluminances (iluminâncias úteis de luz diurna) estabelece uma faixa de valores com limites mínimos (100 lux) e máximos (2.000 lux) (NABIL; MARDALJEVIC, 2006). A definição desse intervalo de iluminâncias, embora bastante amplo, se baseia em trabalhos anteriores sobre níveis mínimos e máximos de iluminação, descritos por Nabil e Mardaljevic (2006). O cálculo do UDI tem o objetivo de quantificar a porcentagem de horas que a iluminação em cada ponto se encontra na margem de "iluminância útil". Como é estabelecido um limite máximo, as ocorrências maiores do que 2.000 lux não são contabilizadas como úteis, inibindo soluções que permitem o excesso de incidência de radiação direta.

Em artigo posterior, Mardaljevic et al. (2012) estendem o limite superior da UDI de 2.000 para 3.000 lux, o que aumenta a tolerância da métrica com a incidência de radiação solar. Os autores definiram os seguintes intervalos de iluminância:

(a) abaixo de 100 lux: iluminação insuficiente;

(b) entre 100 e 300 lux: iluminação suplementar;

(c) entre 300 e 3000 lux: iluminação autônoma; e

(d) acima de 3000 lux: excesso de iluminação.

Apesar da vantagem de capturar o cenário sempre cambiante da iluminação natural ao longo do ano, procedimentos de cálculo dinâmico da luz diurna são mais demorados. Ainda que exista potencial para auxiliar no processo decisório, é um tipo de simulação mais adequada para comparar poucas alternativas de projeto.

Mesmo com o aperfeiçoamento das grandezas de avaliação da iluminação natural, é comum que estudos envolvendo simulação computacional abordem variáveis secundárias. Essas variáveis podem estar relacionadas a aspectos térmicos, energéticos ou de qualidade da iluminação. A abordagem de um critério secundário de desempenho evidencia a necessidade de evitar o excesso de iluminação natural provocada pela incidência de radiação solar direta. Portanto, ainda que envolvam grandezas diversas, os fenômenos associados a esses critérios de desempenho compartilham a mesma causa - incidência de radiação excessiva - e podem ser resolvidos pelas mesmas soluções - dentre elas o sombreamento de aberturas.

A influência de elementos de sombreamento é frequentemente associada à qualidade de iluminação - apesar da dificuldade de mensuração. O impacto de proteções solares na qualidade da iluminação foi investigado em pesquisa desenvolvida por Dubois (2003). Foram realizadas simulações em diversos horários em situações de solstícios e equinócio. A autora selecionou critérios de desempenho associados às iluminâncias internas, à uniformidade da iluminância e contraste de luminâncias. O estudo compara soluções sem proteção solar (com películas branca e cinza), toldos com duas cores diferentes (azul e branco), uma marquise superior e brises horizontais inclinados $\left(45^{\circ}\right)$ e sem inclinação. A dificuldade na análise dos resultados é provocada pelo conflito entre as variáveis escolhidas: os casos com maiores valores de iluminância apresentam também luminâncias mais altas (brises horizontais, marquise e toldo branco). Segundo a autora, os brises com inclinação de $45^{\circ}$ e a película branca no vidro apresentaram resultados mais equilibrados - ainda que o vidro com película branca possa causar ofuscamento quando o sol incide diretamente.

Uma abordagem análoga é realizada por Ho et al. (2008), que realizam simulações de diversas configurações de prateleiras de luz, com modificações de altura e geometria numa sala de aula com iluminação unilateral com janelas de orientação sudeste em Taiwan. São calculadas as iluminâncias internas e uniformidades nas mesas de trabalho. No estudo, são avaliados cenários em que a iluminação artificial é parcialmente acionada na sala. Resultados indicam que o uso de proteções solares acarreta redução de iluminâncias e aumento da uniformidade. Contudo, para obter valores aceitáveis de uniformidade, seria necessária a integração com o sistema de iluminação artificial, por se tratar de ambiente com janelas em uma parede específica.

As pesquisas que trabalham com abordagens de simulação tradicionais envolvendo iluminação natural e sombreamento partem de uma definição a priori dos elementos de sombreamento testados, o que requer certo conhecimento para que sejam simulados casos pertinentes. Pela quantidade de variáveis a serem avaliadas, os procedimentos se limitam à comparação de alguns poucos casos pré-estabelecidos. Consequentemente, em uma aplicação projetual desses procedimentos, podem-se perder oportunidades de atingir níveis mais elevados de desempenho, pois não necessariamente o melhor caso dentre um pequeno grupo de alternativas seria a melhor solução e um universo mais amplo de possibilidades. 


\section{Projeto generativo com algoritmos genéticos}

O processo de projeto generativo envolve a interpolação automatizada de variáveis com vistas a atingir determinado(s) objetivo(s) de desempenho. A possibilidade de explorar soluções em um escopo mais amplo do que seria possível com métodos tradicionais é certamente a grande vantagem na aplicação dessa tecnologia (SINGH; GU, 2012).

Dentre as diversas técnicas disponíveis, o uso de algoritmos genéticos, além de ser das mais difundidas, é a de mais fácil entendimento. Algoritmos genéticos tão técnicas computacionais análogas ao processo de evolução das espécies (GERO; KAZAKOV, 2001). Assim, um algoritmo genético é uma representação computacional da teoria da evolução proposta por Darwin e tem o objetivo de buscar soluções "evoluídas" de acordo com o objetivo definido.

Os genes, a serem interpolados inúmeras vezes, são as variáveis do modelo que estão sujeitas a alterações. Os objetivos, definidos pelo usuário, são valores numéricos que se deseja maximizar ou minimizar e representam critérios de desempenho.

São simuladas gerações de populações com dezenas de casos (valores comumente usados variam entre 50 e 100 casos). Os genes (ou variáveis) dos casos mais eficientes (de acordo com os objetivos estabelecidos) terão mais chance de serem transmitidos para gerações subsequentes. A evolução das soluções tende a se estabilizar quanto maior for o número de gerações simuladas.

Como esse processo requer milhares de simulações, a aplicação de um algoritmo genético acaba sendo pouco viável para simulações mais complexas, como cálculos anuais de iluminação natural, sobretudo em situações de projeto, que envolve respostas rápidas e limitações de tempo.

No meio acadêmico, a depender da capacidade de processamento e disponibilidade de tempo, é possível usar recursos de projeto generativo em simulações mais demoradas. A aplicação de algoritmo genético simplificado foi realizada por Torres e Sakamoto (2007). O estudo se propôs, segundo os autores, a maximizar a economia de energia, reduzir desconforto visual e aumentar a penetração da luz natural a partir das alterações de 21 parâmetros associados à geometria e refletividade de janelas envidraçadas e proteções solares. O procedimento dificilmente poderia ser realizado se não fossem aplicadas simplificações no modo de cálculo do ofuscamento, na caracterização do céu e na própria configuração do algoritmo genético. Foi adotada uma população de 10 casos e elitismo absoluto (apenas os melhores casos são selecionados para cruzamento). Para evitar uma convergência prematura, foi prevista a inclusão de três casos da geração anterior de forma aleatória. Depois de 200 gerações, verificou-se que os resultados haviam se estabilizado desde a centésima geração. O artigo, contudo, se concentra mais na descrição do método e não apresenta as soluções otimizadas.

Em estudo que envolve o desenvolvimento e teste de algoritmo genético, Kirimtat et al. (2016) realizam avaliação de dois objetivos: maximizar a quantidade de pontos entre 100 e 2.000 lux (UDI) e minimizar o consumo energético. O modelo apresenta três variáveis: quantidade de brises horizontais, profundidade das lâminas e ângulo. Foram realizadas simulações de 30 gerações de 100 casos cada uma. Por se tratar de simulações anuais, com tempo médio de 18 minutos por simulação, o processo de cálculo levou 90 horas para conclusão.

Dois tipos de otimização podem aplicar algoritmos genéticos. O primeiro consiste em avaliações de critério único. O objetivo da simulação deve ser baseado em valor numérico único. É possível desenvolver equações que sintetizem, em um único número, o desempenho de vários critérios de desempenho. Contudo, as soluções evoluídas refletirão os pesos atribuídos para cada critério na equação. Havendo alguma falta de clareza sobre a importância relativa de cada objetivo, os resultados obtidos podem ser inconsistentes. O componente 'Galapagos', já incluso no Grasshopper, é certamente a ferramenta mais usada nessa categoria.

Para avaliações de até 5 critérios simultâneos, o plugin Octopus (VIERLINGER, 2013) apresenta os resultados plotados em gráfico tridimensional. O programa adota o método de cálculo Hypervolume Indicator, solução mais eficiente do que os tradicionais métodos SPEA e SPEA2 para que as soluções convirjam para a "fronteira de Pareto"- linha limítrofe formada pelos casos de melhor desempenho em dois ou mais critérios determinados. De acordo com o princípio de Vilfredo Pareto, uma solução com múltiplas medidas de qualidade não pode melhorar um objetivo sem degradar outro(s). Assim sendo, avaliações multicritério não resultam em apenas um caso de melhor desempenho, já que os critérios se afetam mutuamente. O resultado é um grupo de soluções que não serão igualmente eficientes em um mesmo critério: a escolha final depende da prioridade que o projetista atribui a cada objetivo. 
A fronteira de Pareto é facilmente identificável em avaliações levando em conta dois critérios (Figura 1). Em problemas com três ou mais critérios, a fronteira é composta por polígonos tridimensionais.

\section{Método}

A pesquisa envolveu duas etapas principais, que foram subdivididas em procedimentos menores (Figura 2). Primeiramente, foi feita a elaboração de uma ferramenta paramétrica de otimização multicritério que segue determinado fluxo de trabalho e pode ser configurada segundo as especificidades de cada projeto. Em seguida, foi realizado um teste desse modelo para uma sala hipotética de orientação oeste aplicando o arquivo climático da cidade de Campina Grande, na Paraíba.

O processo de elaboração do modelo paramétrico foi subdividido nos seguintes procedimentos (Figura 2):

(a) modelagem dos elementos geométricos: modelagem paramétrica de um ambiente genérico com janela e possibilidade de escolher um dos quatro tipos de proteções solares que foram modeladas: brises horizontais, brises verticais, prateleira de luz e brises mistos (horizontal e vertical); e

(b) definições dos tipos de simulação e objetivos: para que as soluções possam ser otimizadas, foram definidos os critérios de otimização do modelo e inseridos os componentes de preparação (propriedades de materiais) e cálculo. Essa etapa contém definições importantes, como que tipos de simulação devem ser realizadas em cada fase do processo.

O teste prático da ferramenta se dividiu em quatro etapas (Figura 2):

(a) definição das variáveis fixas do modelo: foram definidas as dimensões da sala, abertura, tipo de proteção solar e materiais de todas as superfícies;

(b) identificação do horário de maior incidência de radiação solar na janela: com o uso de avaliação de critério único (Galapagos), foram realizadas simulações com o objetivo de identificar a hora do ano que apresenta maior incidência de radiação solar na abertura;

(c) otimização multicritério: foi definido um cenário de simulação (variáveis geométricas fixas e propriedades dos materiais) no qual foi aplicado um algoritmo que reproduz a transferência de genes através de gerações. Após 35 gerações com população de 100 indivíduos cada, foram selecionados seis casos que atendam a um ou mais dos três objetivos estabelecidos; e

(d) simulações anuais dos melhores casos: com simulações anuais, foram comparados os desempenhos dos casos selecionados através de quantificações de iluminação e sombreamento.

\section{Modelagem dos elementos geométricos}

A elaboração do modelo tem o objetivo de fornecer suporte a fases iniciais de projeto. Para permitir que o programa seja ágil na produção de resultados, é necessário que os elementos geométricos sejam simplificados, sobretudo se considerarmos que qualquer processo de otimização através de ferramenta de projeto generativo requer milhares de iterações.

O modelo paramétrico é composto por um ambiente com uma janela externa e uma obstrução frontal (Figura 3). Através da modificação de parâmetros, as dimensões do ambiente, da obstrução e da janela podem ser modificadas. A esse modelo foram adicionadas opções de proteções solares: proteção horizontal, vertical, prateleira de luz e proteção mista (horizontal e vertical combinadas).

Mesmo que o modelo seja de uma edificação térrea, é possível configurar as propriedades ópticas da superfície do piso para que esta não tenha influência na incidência de iluminação natural no ambiente, simulando um cenário de ambiente em um contexto de um prédio com vários pavimentos. Todas as margens de parâmetros aqui estabelecidas podem ser facilmente modificadas manualmente ao editar os componentes que guardam essa informação. Logo, caso haja necessidade, por exemplo, de uma obstrução com largura maior do que $20 \mathrm{~m}$, a edição do slider específico - componente que permite a alteração dos valores - não apresenta grande dificuldade mesmo para quem não domina a ferramenta.

O dimensionamento das proteções solares também ocorre por meio de parâmetros manipuláveis pelo usuário (Quadro 1). Para permitir rapidez nas iterações do modelo, não foram consideradas as espessuras de paredes, proteções solares, pisos e tetos.

A modelagem geométrica de cada tipo de proteção solar foi realizada separadamente a partir da geometria da janela. Para permitir que o usuário da ferramenta selecione um tipo de proteção, os resultados geométricos 
foram conectados como inputs do componente stream filter, que faz com que se possa escolher (filtrar) um dos caminhos conectados.

Figura 1 - Fronteira de Pareto: melhores casos estariam próximos à origem

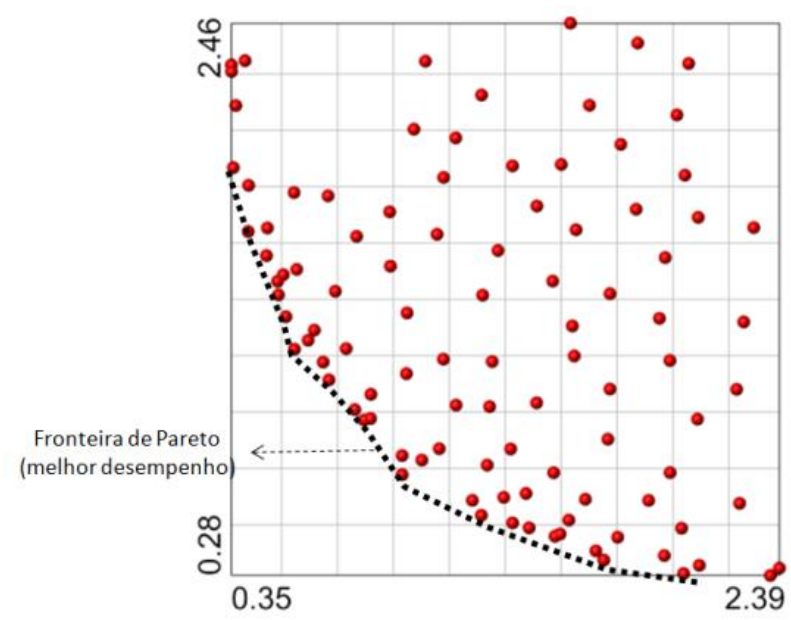

Fonte: adaptado de Vierlinger (2013).

Figura 2 - Esquema dos procedimentos metodológicos

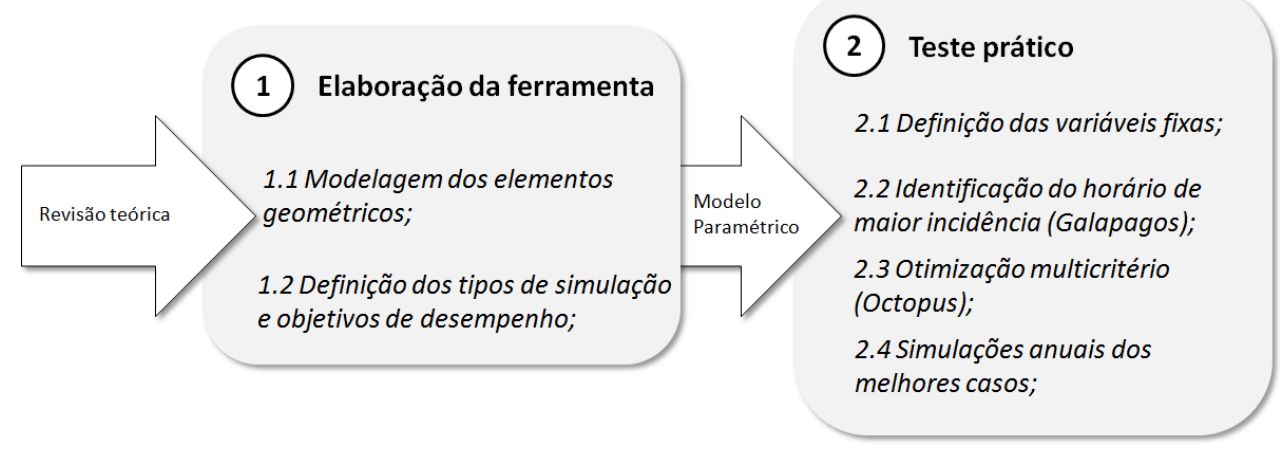

Figura 3 - Possibilidades de variações do modelo geométrico do ambiente e contexto

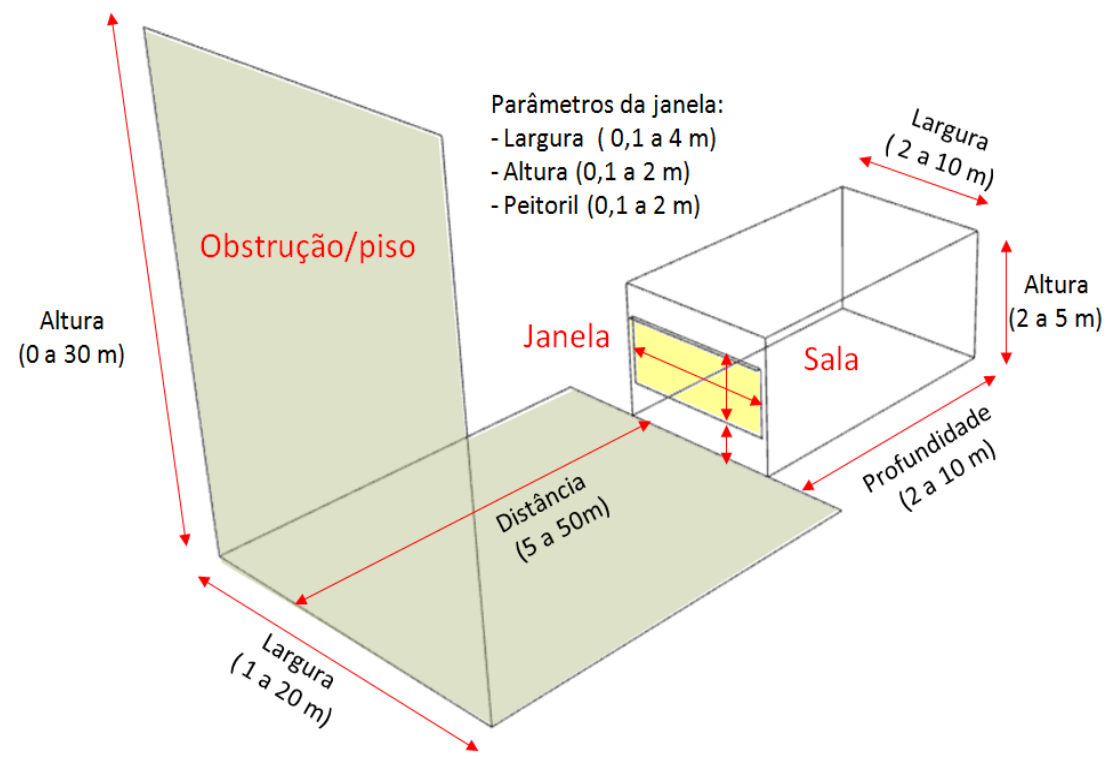

Sombreamento com iluminação: desenvolvimento e teste de modelo paramétrico para facilitar o projeto de proteções 


\section{Quadro 1 - Parâmetros das proteções solares}

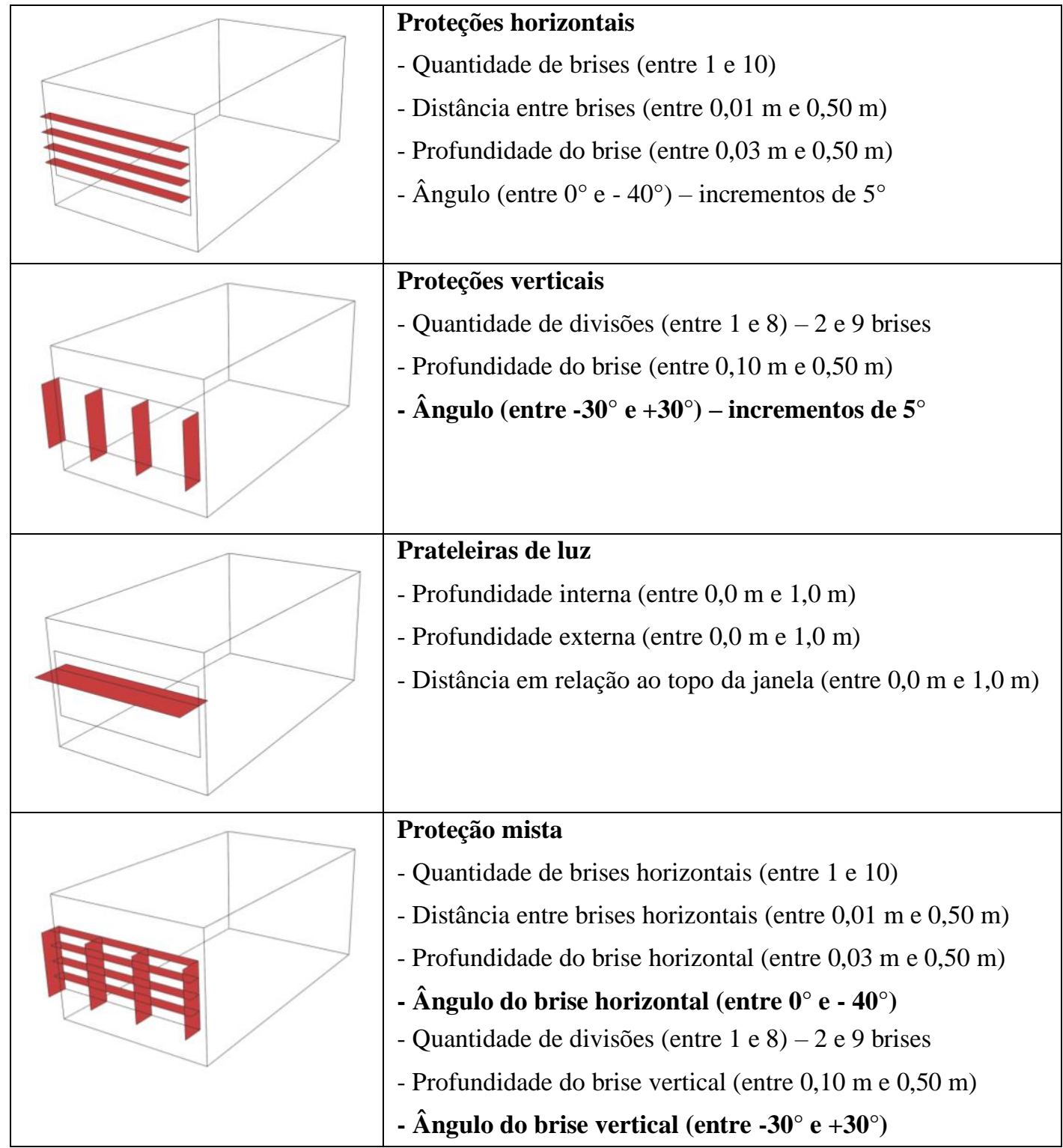

\section{Definições dos tipos de simulação e objetivos de desempenho}

A segunda etapa de modelagem consiste na definição dos tipos de simulação a serem realizados e na preparação para que os plugins de simulação reconheçam a geometria produzida.

Para que o modelo possa ser usado em situações práticas com uso de algoritmos genéticos (projeto generativo), é necessário que o tempo de cada simulação seja muito reduzido (não mais do que 10 segundos por simulação), pois o processo de otimização requer milhares de simulações para produzir resultados úteis. Assim, seria inviável o uso de simulações anuais para incidência iluminação natural com a finalidade de fornecer suporte a atividades de projeto, pois o processo de otimização levaria dias para gerar soluções de bom desempenho.

Embora não seja viável a realização de simulações anuais de iluminação, é possível realizar simulações anuais da incidência de radiação solar na janela. Isso ocorre porque o tempo necessário para essa simulação é bastante curto (por volta de três segundos, com variações que dependem da complexidade da proteção solar). Para viabilizar o processo de otimização, a simulação anual de radiação foi combinada com uma simulação estática de iluminâncias internas, cuja duração gira em torno de 10 segundos com 2 reflexões no ambiente (ambient bounces). 
O cenário a ser simulado na simulação estática deve envolver a incidência solar na fachada da abertura. Caso a incidência de iluminação não seja suficiente com sol frontal, certamente não será em situações de menor disponibilidade de luz.

Seguindo as definições desses processos de simulação, foi estabelecido um fluxo de trabalho dividido em cinco etapas:

(a) identificação do horário com maior incidência de radiação na janela: tendo como parâmetros modificáveis os meses do ano, dias e horas, são feitas interpolações automáticas no Galapagos com o objetivo de identificar a hora do ano em que há maior incidência de radiação direta na superfície da abertura sem o elemento de proteção solar. Foi inserido no modelo um diagrama de trajetória solar para que o usuário da ferramenta possa visualizar o vetor de incidência do sol em relação à janela. Caso a situação de projeto exija uma resposta mais rápida do programa e considerando que os cálculos de radiação solar, por serem anuais, não são afetados por esse procedimento, a definição da hora crítica pode ser feita manualmente sem prejudicar o processo de otimização - desde que seja uma posição de sol frontal à abertura;

(b) otimização: após selecionado o horário crítico e o tipo de proteção a ser simulada, pode-se iniciar o processo de avaliação multicritério. Podem ser configurados até três objetivos de desempenho para a simulação e os resultados podem ser visualizados no gráfico tridimensional do Octopus;

(c) seleção parcial: durante o processo de otimização, pode-se interromper o processo e marcar aquelas soluções dentro da fronteira de Pareto que estão mais de acordo com suas prioridades de projeto. Caso novas gerações sejam simuladas, é possível que alguns desses casos saiam da fronteira de Pareto, sendo suplantadas por soluções mais eficientes. Ainda assim, selecionar casos das primeiras gerações pode ser interessante para estabelecer um parâmetro de comparação com soluções futuras. Não há como predizer a quantidade de gerações que uma avaliação multicritério com vários parâmetros necessitará para convergência. Essa informação varia não somente de acordo com o número de genes (variáveis), mas com o tipo de problema a ser otimizado. Logo, o fim da simulação em situações de projeto depende bastante do tempo disponível. É interessante observar que, após duas ou mais dezenas de gerações, já é possível identificar os padrões associados às soluções de maior desempenho nos objetivos priorizados pelo projetista; e

(d) Simulação anual: com poucos casos para comparação, é feita uma simulação anual de iluminâncias internas para facilitar a escolha final.

\section{Preparação para simulação}

A primeira parte de preparação do modelo consiste na atribuição de materiais. Para tornar o uso da ferramenta mais intuitivo, foram usados componentes de cores de materiais para extração das refletâncias dos materiais de superfícies opacas. Desse modo, a partir da seleção de determinada cor, obtém-se automaticamente as refletâncias do vermelho, azul e verde. Propriedades de rugosidade e especularidade podem ser inseridas manualmente no mesmo componente. A seleção do vidro pode ser feita através da transmissividade média do vidro. Com base no valor inserido, é extraído da biblioteca do radiance um vidro com dados ópticos de valores mais aproximados aos inseridos. Devido à grande quantidade de vidros disponíveis, a discrepância entre o valor inserido e o vidro selecionado é pequena. A vantagem, nesse caso, é a adoção de todas as propriedades ópticas de um vidro real.

\section{Definição dos tipos de simulação}

O passo seguinte consiste na definição dos tipos de cálculos que podem ser realizados. Para o uso da ferramenta de projeto generativo, é essencial que tenhamos pelo menos um tipo de simulação de iluminação natural e outro de incidência de radiação. Ao todo, as seguintes simulações foram agregadas ao modelo e podem ser ativadas ou desativadas conforme o interesse do usuário (seguindo o ordenamento do fluxo de trabalho):

(a) incidência de radiação direta na superfície do vidro $\left(\mathrm{kWh} / \mathrm{m}^{2}\right)$ sem proteção solar: para a identificação do horário crítico, foi definido um fluxo separado para a simulação da janela não sombreada. Como a incidência na superfície não obstruída é uniforme, é usado apenas um ponto central na janela. Desse modo, o tempo necessário para cada iteração é reduzido. Caso exista uma obstrução frontal, que não foi o caso do teste prático realizado, o tamanho do grid pode ser ajustado para uma simulação mais precisa;

(b) trajetória solar: para permitir a visualização da orientação da sala em relação ao percurso solar e, consequentemente, a identificação de cenários mais críticos em termos de radiação solar, foi adicionado esse componente auxiliar; 
(c) simulação anual de radiação solar na superfície do vidro $\left(\mathrm{Wh} / \mathrm{m}^{2}\right.$ por dia): cálculo da incidência média diária de radiação em malha de pontos distanciados a cada $10 \mathrm{~cm}$ na superfície da janela. A escolha por trabalhar com incidência de radiação solar $\left(\mathrm{W} / \mathrm{m}^{2}\right)$ em comparação a outras métricas, como a exposição anual da luz do dia (ASE), justifica-se por duas razões: trata-se de uma simulação mais eficiente para se trabalhar com malhas mais refinadas e representa de forma mais direta o potencial de ganho de calor da abertura;

(d) iluminâncias no plano de trabalho (lux): foi configurado um plano de trabalho a $80 \mathrm{~cm}$ do chão e uma malha de pontos espaçados a cada $0,5 \mathrm{~m}$; e

(e) simulação anual de iluminação (\% das horas): usando as mesmas configurações de malha, é calculada porcentagem de horas de iluminância útil (UDI na faixa entre 100 a 2.000 lux) e com iluminâncias entre 300 e 750 lux - faixa prescrita pela ABNT (2013) que compreende os limites inferiores de iluminância de entorno imediato e superiores para iluminação do plano de trabalho para atividades de escritório.

\section{Definição dos objetivos a serem selecionados no processo de otimização}

A aplicação de algoritmo genético requer a definição de um ou mais objetivos de desempenho. Embora o plugin Octopus trabalhe com até cinco critérios simultâneos, a visualização dos resultados com três objetivos é facilitada pela existência de três eixos correspondentes no gráfico. Ademais, o aumento de objetivos pode provocar sobrecarga de processamento, ocasionando travamentos.

Mesmo com a limitação de três objetivos por vez, foram desenvolvidas quatro possibilidades de objetivos, a serem selecionadas conforme a preferência do usuário da ferramenta:

(a) maximizar número de pontos com iluminância entre 300 e 750lux;

(b) minimizar radiação solar direta anual na janela $\left(\mathrm{Wh} / \mathrm{m}^{2}\right.$ por dia);

(c) maximizar uniformidade da iluminação; e

(d) maximizar iluminância média (lux).

O modelo paramétrico final é composto por 16 partes principais, listadas na Figura . Em verde, são agrupadas as variáveis geométricas e de modificações de materiais do modelo. A concentração das variáveis em uma barra vertical busca facilitar a configuração do modelo. No item 3 podem ser ativadas e desativadas todas as simulações realizadas.

Os itens 4, 5, 6, 7 e 8 em vermelho, são destinados à modelagem e representação geométrica de todos os elementos (sala, obstrução externa e proteções solares). As geometrias são conectadas a componentes de atribuição de materiais (item 9), necessários para a simulação de iluminâncias internas.

Todos os componentes de simulação ou tratamento de resultados são apresentados em amarelo, com as simulações de percurso solar (10), radiação solar anual e estática (11 e 13), iluminância (12) e simulações anuais de iluminação (14). A aplicação de algoritmos genéticos com avaliação multicritério é feita no item 15. Os itens de numeração 16 são destinados à configuração de resultados (malhas e legendas).

Embora o aspecto do arranjo final dos componentes apresente complexidade, a maioria das operações que fazem parte do modelo não precisa ser acessada pelo usuário da ferramenta, podendo ser futuramente agrupadas em clusters. Dentre os componentes mais importantes, o uso da ferramenta passa necessariamente pelos seguintes passos:

(a) alteração das variáveis geométricas do ambiente, contexto e materiais;

(b) definição do horário de incidência crítica, no item 13, com aplicação do Galapagos (Figura 4);

(c) ativação das simulações de radiação solar anual e iluminância no horário de maior incidência, nos componentes sequenciais do item 3 (Figura 4);

(d) conexão dos genes e objetivos de desempenho ao componente do Octopus, dando início ao processo de otimização, no item 15 (Figura 4). Durante essa etapa, pode-se pausar e verificar os casos que se aproximam mais do desempenho desejado pelo projetista (que, nesse caso, dependem do nível de prioridade que se dá ao sombreamento das aberturas); e

(e) após marcação dos casos de interesse, desativação da simulação estática de iluminação e ativação das simulações anuais para um último comparativo, também no item 3 (Figura 4). 
Figura 4 - Modelo paramétrico final

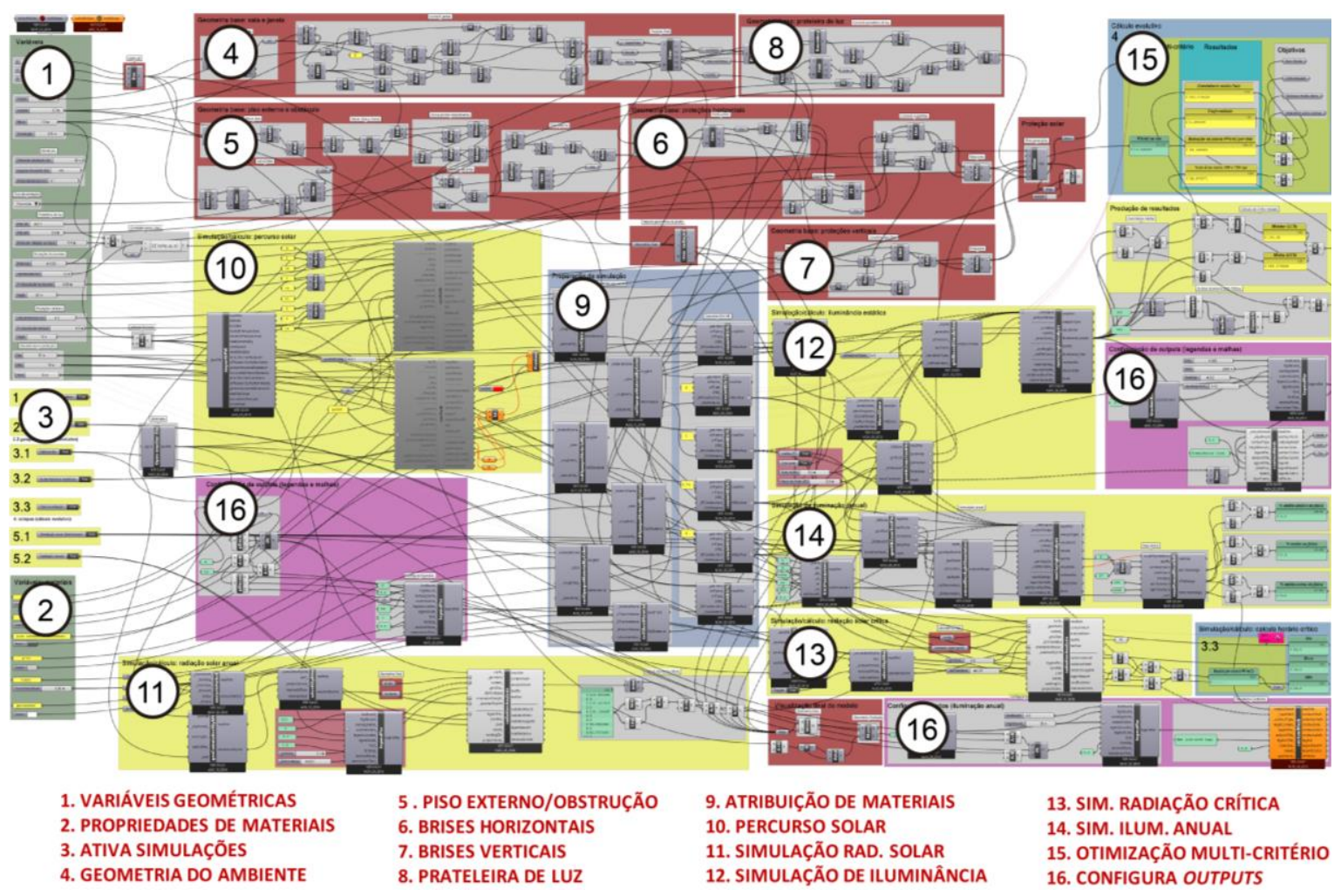

\section{Teste da ferramenta: otimização multicritério}

Nessa etapa, foram definidas as variáveis fixas que compõem o cenário específico simulado. As seguintes configurações foram usadas:

(a) sala: $4 \mathrm{~m}$ (largura) x $7 \mathrm{~m}$ (profundidade) x $3 \mathrm{~m}$ (altura) sem obstrução frontal com todas as cores internas brancas (90\% de refletância);

(b) janela: vidro claro (87\% de transmissão visível) 3,7 m (largura) x 1,5 m (altura) com peitoril de 0,8 m;

(c) orientação: oeste (azimute $270^{\circ}$ );

(d) arquivo climático: Campina Grande, PB; e

(e) data e horário da simulação estática de iluminância: 20/10 às 14 horas - obtidos por meio de aplicação do Galapagos (hora com maior incidência de radiação na superfície da abertura sem proteção solar).

Foi selecionado um cenário de abertura oeste justamente pela complexidade de atender a critérios de iluminação e sombreamento no caso de uma incidência solar tão frontal em relação à janela.

O tipo de proteção solar escolhido foi de brises mistos (cor clara), pois apresenta maior quantidade de variáveis manipuláveis, o que enriquece a análise do processo de otimização. Os seguintes parâmetros serão manipulados como genes no modelo de cálculo evolutivo:

(a) distância entre brises horizontais $(\mathrm{m})$ : valores variam entre 0,01 e 0,50.

(b) quantidade de brises horizontais: entre 1 e 10 (foi aplicada uma expressão condicional para que a multiplicação entre as distâncias entre proteções solares e a quantidade de brises não exceda a altura da janela, atrapalhando a análise dos resultados).

(c) ângulo de brise horizontal: entre 0 e $-40^{\circ}$ (em intervalos de $5^{\circ}$ );

(d) profundidade de brises verticais: entre 0,1 e 0,5 ;

(e) quantidade de brises verticais: entre 2 e 9 ;

(f) ângulo de brise vertical: entre $30^{\circ}$ e $-30^{\circ}$ (em intervalos de $5^{\circ}$ ). 
A decisão de quais objetivos serão usados no modelo evolutivo é crucial, pois as soluções irão se adaptar para atender aos critérios numéricos escolhidos.

Estudos iniciais foram feitos para verificar as características de soluções otimizadas para diferentes combinações de objetivos. O uso da uniformidade de iluminação como objetivo, por se tratar de um modelo com iluminação unilateral, entra em conflito com o objetivo primordial de maximizar a iluminação natural, gerando soluções de proteções solares muito fechadas, com valores de iluminância mais próximos do limite inferior de 300 lux.

Dessa maneira, foram adotados os seguintes objetivos:

(a) minimizar radiação solar direta anual na janela $\left(\mathrm{Wh} / \mathrm{m}^{2}\right.$ por dia);

(b) maximizar número de pontos com iluminância entre 300 e 750 lux; e

(c) maximizar iluminância média (lux).

Essa combinação de objetivos representa melhor o equilíbrio entre critérios de iluminação e sombreamento. Como consequência dos três critérios, as melhores soluções devem obstruir a radiação direta, atingir o máximo percentual de pontos entre 300 e 750 lux sem reduzir consideravelmente a média de iluminâncias internas - o que seria um indicativo que os valores não estariam próximos ao limite inferior de 300 lux.

A configuração do algoritmo evolutivo adotou a probabilidade de mutação de cada parâmetro de 4,8\% (valor próximo do limite inferior), com taxa de mutação de 0,3 (valor um pouco abaixo do intermediário). Esses valores minimizam a probabilidade de mutação de determinado gene (parâmetro) e, quando essas mutações ocorrem, tendem a não ser significativas. Os valores mais baixos se justificam, pois a aleatoriedade das mutações não contribui tanto para a resolução desse tipo de problema. O crossover rate (taxa de cruzamento), valor que representa a probabilidade de cruzamento de genes entre soluções, é de 0,80 (valor padrão do programa). Foram adotadas populações de 100 casos e elitismo de $20 \%$, que compreendem os casos que terão maior probabilidade de terem seus genes combinados em futuras gerações.

Não foi estabelecida a priori uma quantidade máxima de gerações, mas um tempo de simulação que pudesse estar inserido entre o fim do horário comercial e o início da manhã. Logo, em uma situação de prática profissional, poderia se executar o processo de otimização sem perda de produtividade.

\section{Resultados e discussões}

\section{Identificação de horário crítico}

Depois de definidas as variáveis geométricas do modelo, deve ser iniciada a aplicação de algoritmo genético de critério único para identificar o dia e a hora de maior incidência de radiação na janela não sombreada.

O objetivo do processo evolutivo é, a partir da interpolação entre variáveis dos meses, dias e horas, maximizar a incidência de radiação. Por se tratar de um problema não tão suscetível à convergência, observamos através de alguns testes que a data de maior incidência surge já nas primeiras gerações de casos.

Para permitir maior rapidez, o usuário pode também limitar manualmente o intervalo de tempo a ser considerado na simulação ao editar a faixa de valores do slider referente às horas ou meses do ano. No caso de uma abertura oeste, por exemplo, não faria sentido que o período da manhã fosse calculado.

Depois de 40 gerações de casos simulados no Galapagos, a hora do ano com maior incidência de radiação foi no dia 20 de outubro, às 14 horas, com incidência de $349,1 \mathrm{~W} / \mathrm{m}^{2}$. Conforme pode ser verificado na Figura 5.

A posição do sol em relação à normal da abertura tem angulação horizontal de aproximadamente $7^{\circ}$ para sul e tem altura solar de $47^{\circ}$.

\section{Processo de otimização das proteções solares}

No Octopus, foram simuladas, ao todo, 35 gerações de casos, cada uma delas com uma população de 100 indivíduos. As soluções geradas vão sendo mostradas em gráfico tridimensional, no qual se podem visualizar os três objetivos em eixos (Figura 6). No plugin usado, as melhores soluções estão sempre próximas do cruzamento dos eixos. Consequentemente, todos os valores numéricos que se deseja maximizar (objetivos de iluminação, por exemplo) devem ser multiplicados por -1, ou seja, quanto mais o objetivo é atendido, mais o valor se aproxima da origem. 
Figura 5 - Posição do sol no horário de maior incidência na abertura

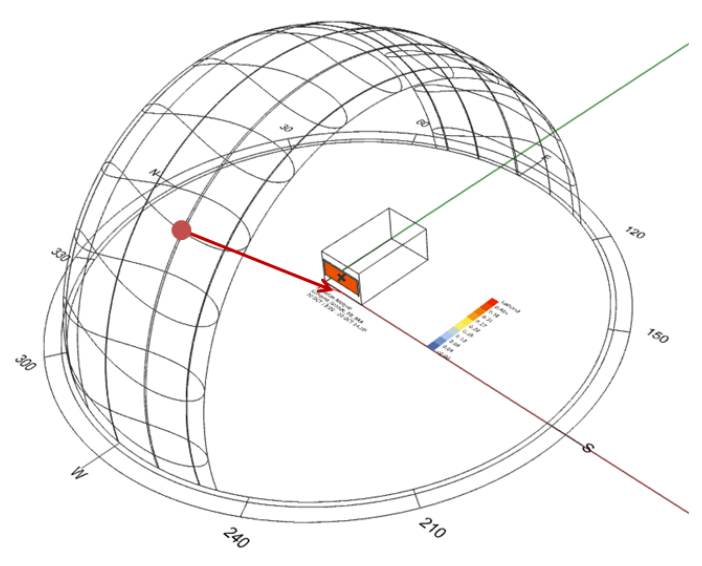

Figura 6 - Gráfico tridimensional de resultados nas gerações $n^{\circ} 15$ e $n^{\circ} 35$

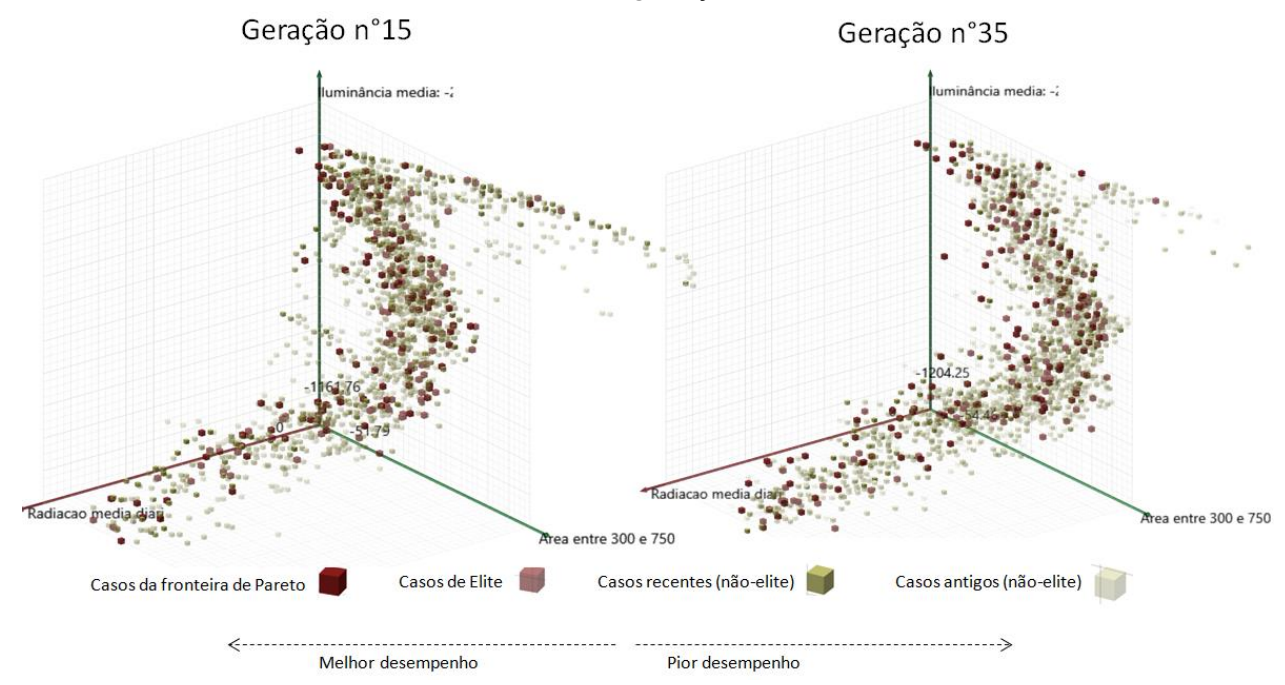

No gráfico da Figura 6, estão plotados os casos que compõem os seguintes grupos:

(a) Fronteira de Pareto (vermelho): são os casos mais eficientes, que mais atendem à combinação de objetivos propostos;

(b) Elite: compõem $20 \%$ dos casos de melhor desempenho e apresentam maior chance de transferência de genes para gerações posteriores;

(c) casos recentes (não elite): casos de uma geração recente que não fazem parte da elite; e

(d) casos antigos (não elite): casos de gerações anteriores que não fazem parte da elite. Ao longo das simulações, os casos com pior desempenho vão desaparecendo do gráfico.

Percebe-se pela distribuição dos casos vermelhos (fronteira de Pareto) é parecida entre as gerações 15 e 35. Não há, no gráfico, uma região particular que apresente concentração de casos maior do que as outras. Pelo contrário, os casos da elite se encontram ao longo de uma curva de forma relativamente bem distribuída.

As diferentes áreas do gráfico apresentam comportamentos distintos de desempenho. As áreas demarcadas no gráfico da Figura 7 indicam três zonas principais de desempenho, exemplificadas através dos casos mostrados na imagem. $\mathrm{Na}$ área vermelha, os resultados apresentam maior incidência de radiação e iluminâncias médias, com desempenho intermediário na porcentagem de pontos entre 300 e 750 lux. A área azul é a que apresenta menor incidência de radiação e menor média de iluminância, mantendo mais de $45 \%$ dos pontos na faixa definida de iluminância. A área verde, localizada próxima do centro do gráfico, apresenta valores intermediários para os três objetivos. 
A escolha dos casos de melhor desempenho depende da prioridade que o projetista atribui aos objetivos da otimização. Trata-se de uma ferramenta para auxiliar a escolha, mas, em último caso, a definição final ainda é feita pelo arquiteto com base nos resultados das simulações e outros critérios que podem fazer parte do projeto e não são contemplados no modelo (viabilidade construtiva, critérios estéticos, etc.). Caso a preferência seja por casos que tenham menor incidência de radiação solar, os casos mais eficientes estarão próximos da origem do eixo referente a esse critério.

Para avaliações mais aprofundadas, foram selecionados os seis casos numerados na Figura 7 e apresentados na Tabela 1 e Figura 8. Em uma situação de projeto, buscar-se-ia selecionar os casos de melhor desempenho conforme o(s) objetivo(s) prioritário(s). Contudo, para ilustrar a aplicação da ferramenta, buscou-se selecionar casos em três áreas distintas do gráfico, com maior variedade de soluções e de resultados.

Figura 7 - Casos da fronteira de Pareto na $35^{\circ}$ geração

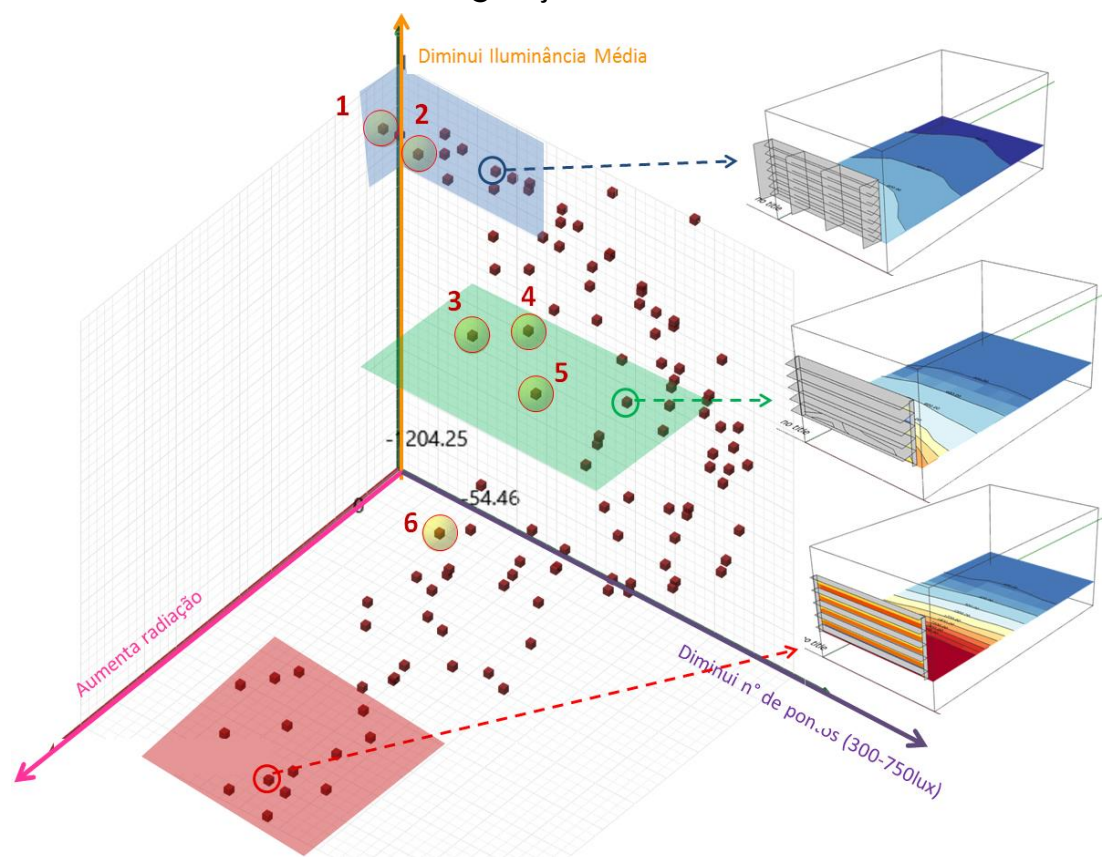

Tabela 1 - Variáveis e resultados dos seis casos selecionados

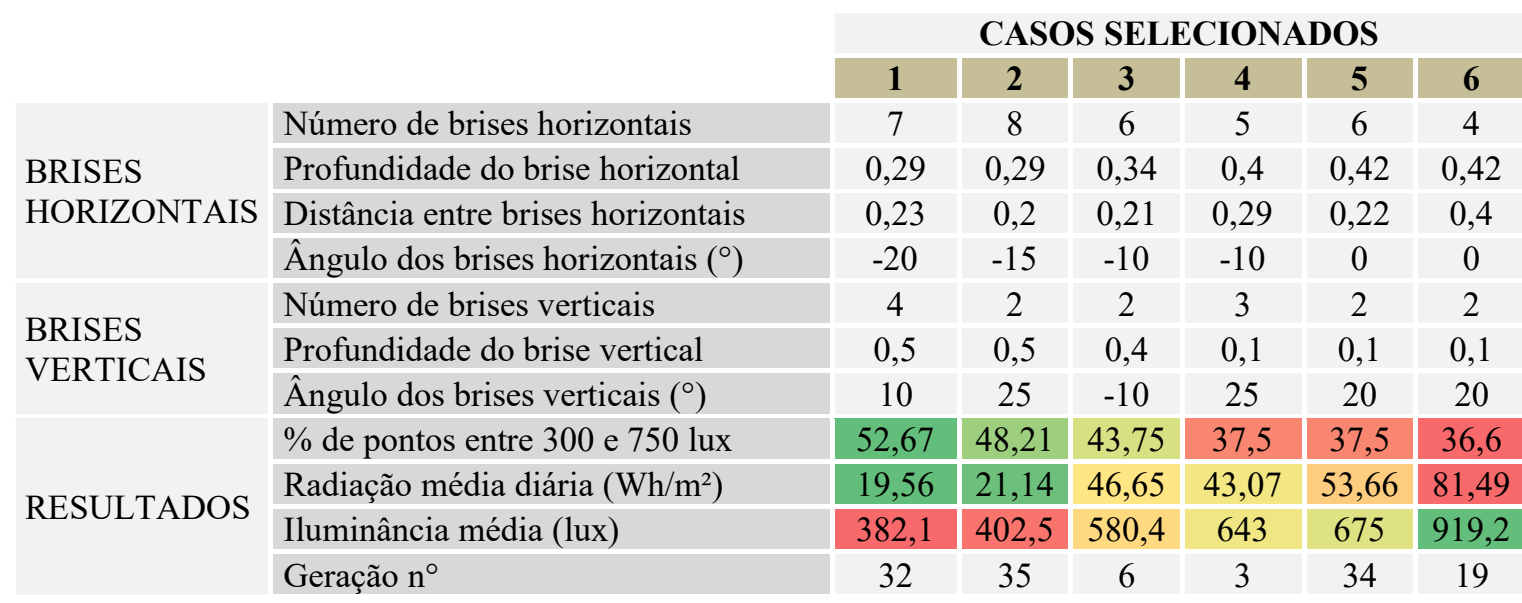


Figura 8 - Casos selecionados para simulações anuais

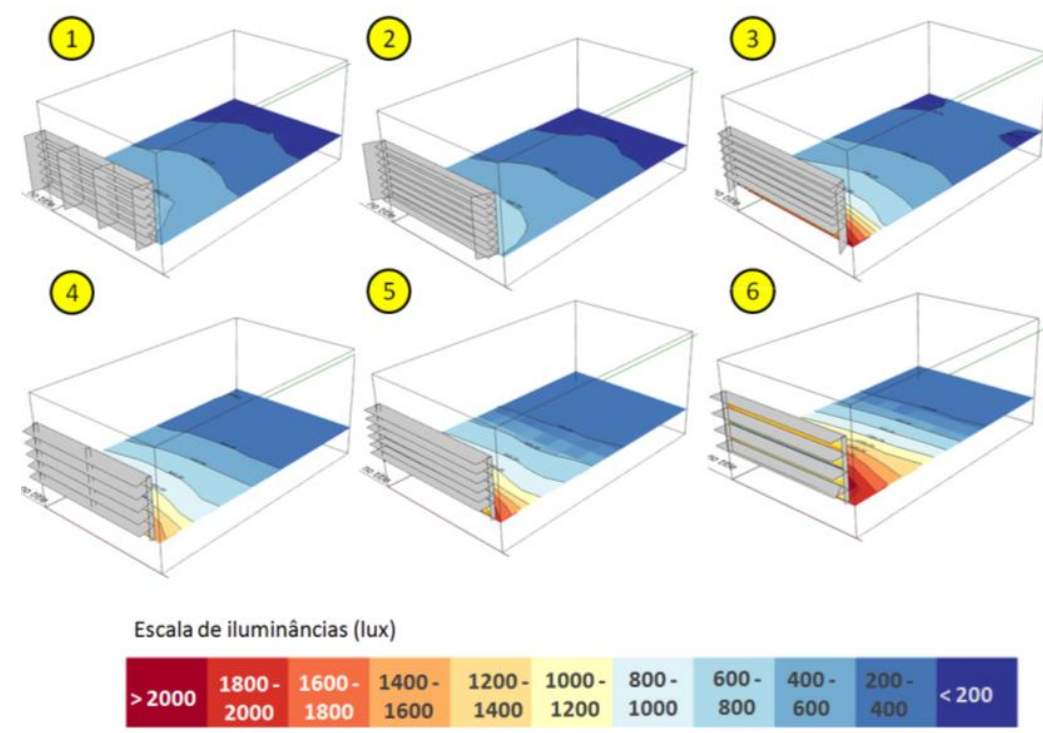

De acordo com a Tabela 1, as seguintes considerações podem ser feitas sobre os resultados apresentados:

(a) os casos 1 e 2 apresentam maior sombreamento e boa distribuição de iluminâncias entre 300 e 750 lux (por volta de $50 \%$ dos pontos). Entretanto, são os casos que apresentam menor média de iluminância no dia simulado;

(b) os casos 3, 4 e 5 apresentam incidência de radiação intermediária (entre $43 \mathrm{Wh} / \mathrm{m}^{2}$ e $53 \mathrm{Wh} / \mathrm{m}^{2}$ ao dia), com comportamentos parecidos nas demais variáveis; e

(c) o caso 6 apresenta maior radiação solar $\left(81.49 \mathrm{~W} / \mathrm{m}^{2}\right.$ por dia) com maior média de iluminância e maior incidência de radiação solar.

Vale observar que, caso fosse adotada a faixa de UDI em vez do intervalo entre 300 e 750 lux, todos os casos teriam uma porcentagem de pontos de iluminância útil consideravelmente maior e parecida entre si, dificultando a diferenciação entre os casos nesse objetivo de desempenho.

Com base na Tabela 2, que apresenta variáveis dos casos selecionados, e Figura 8, que apresenta as soluções de proteção solar, destacam-se os seguintes pontos:

(a) quanto à diversidade de genes (variáveis): há uma variação entre 4 e 8 brises horizontais de profundidade entre $29 \mathrm{~cm}$ e $42 \mathrm{~cm}$. Os resultados indicam que soluções com menor profundidade e maior quantidade de brises apresentaram melhor desempenho em dois dos objetivos. As soluções com menor incidência de radiação também apresentaram ângulos maiores. O impacto dos brises verticais nos resultados é bem menor, considerando a orientação oeste da janela. Houve uma variação entre 2 e 4 brises verticais com profundidades entre $10 \mathrm{~cm}$ e $50 \mathrm{~cm}$;

(b) quanto à geração em que foram criados os casos: três dos casos surgiram a partir da $32^{\circ}$ geração (casos 1,2 e 5). Como o algoritmo não compreende qual a ordem de prioridade que o projetista atribui aos objetivos, soluções com diferentes comportamentos de desempenho continuam sendo geradas mesmo nas últimas gerações - como é o caso da solução $n^{\circ} 5$. Contudo, percebe-se que os dois casos de melhor desempenho (considerando que a iluminância média é um critério secundário) foram obtidos nessas últimas gerações - o que reforça a necessidade de tempo para realizar um número considerável de simulações; e

(c) quanto ao cumprimento dos objetivos: na Tabela 1 foi aplicada uma escala de cores que representa o atendimento a cada objetivo de desempenho. As cores variam entre verde (objetivo cumprido) e vermelho (objetivo não priorizado). Esse comparativo mostra que as soluções 1 e 2 são as únicas a ter desempenho ótimo em dois dos três objetivos propostos.

\section{Simulações anuais}

Com o objetivo de permitir um comparativo mais preciso entre os casos, foi realizada uma simulação anual para quantificar o desempenho dinâmico da iluminação natural. A grandeza usada para representar o 
desempenho lumínico é o useful daylight illuminance (UDI), que consiste na porcentagem das horas de ocupação em que cada ponto tem iluminância entre 100 e 2.000 lux. Para complementar a análise, também foi feito o mesmo cálculo na faixa entre 300 e 750 lux, que representa uma faixa de valores prescrita pela ABNT (2013) para iluminâncias mínimas de entorno imediato (300 lux) e iluminâncias máximas para áreas de tarefa (750 lux) em ambientes de escritório.

Por envolver o efeito de iluminação indireta provocado por proteções solares, no cálculo de iluminação anual foram configuradas 5 reflexões de luz (ambient bounces). As demais configurações foram ajustadas priorizando a precisão, mesmo se tratando de um modelo geometricamente simplificado. A duração média de cada simulação foi pouco mais de 4 minutos.

As seguintes conclusões podem ser tiradas a partir da análise dos resultados das simulações anuais de iluminação (Figura 9), juntamente com os dados já calculados de radiação solar:

(a) o excesso de luz é o maior problema: como se trata de uma abertura voltada para oeste, os casos que apresentam proteções solares mais abertas ganham muita luz direta, tendo considerável porcentagem de pontos acima de 2.000 lux;

(b) falta de luz não é o problema: por se tratar de uma abertura de dimensões generosas com proteções horizontais de cor clara, que também contribuem com a iluminação ao refletir a luz da abóboda celeste para o interior do ambiente, há razoável incidência de luz mesmo no período da manhã. As porcentagens médias de horas de iluminância abaixo de 100 lux são irrisórias;

(c) as melhores soluções são as mais sombreadas: a solução 1, que apresentou melhor sombreamento entre todos os casos da fronteira de Pareto, obteve $70 \%$ das horas em média entre 100 e 2.000 lux e $17 \%$ entre 300 e 750 lux; e

(d) em todos os casos, a porcentagem de horas na faixa de iluminância útil é maior no fundo da sala (entre $60 \%$ e $90 \%$ ) e menor na área próxima da abertura (entre $20 \%$ e $40 \%$ ).

Figura 9 - Resultados de simulações anuais: iluminação (UDI) e radiação solar na janela
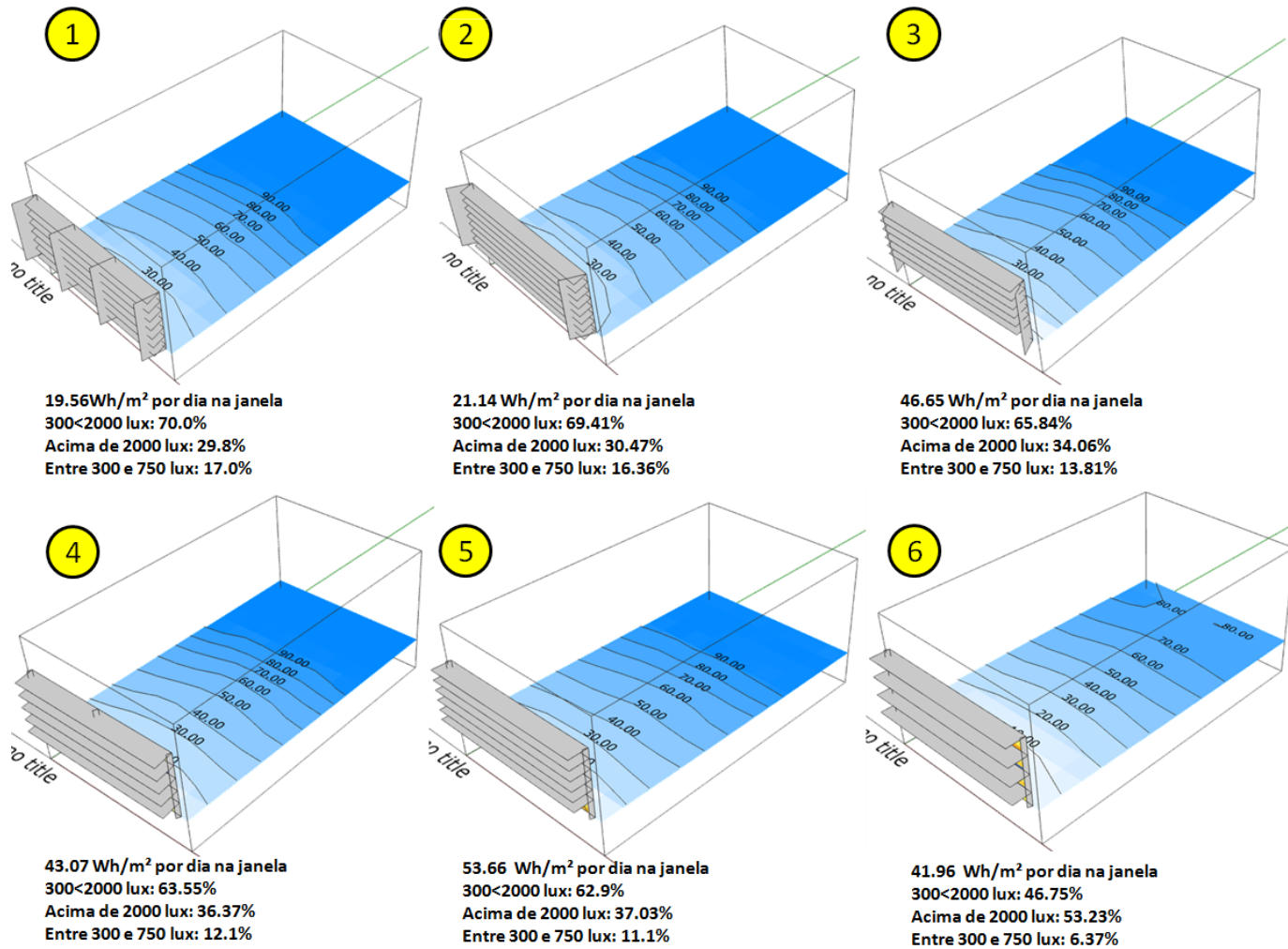

$21.14 \mathrm{Wh} / \mathrm{m}^{2}$ por dia na jane $300<2000$ lux: $69.41 \%$ Acima de 2000 lux: $30.47 \%$

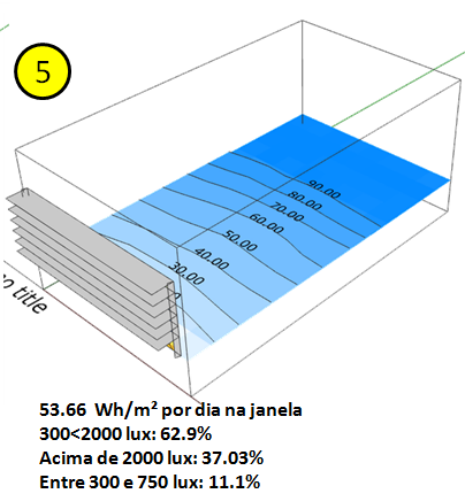

Acima de 2000 lux: $34.06 \%$

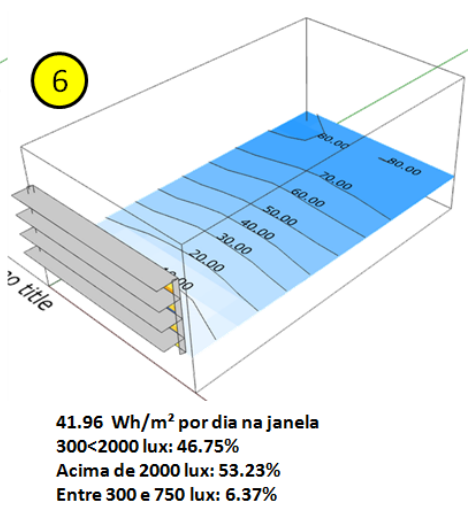


Os resultados das simulações anuais complementam o entendimento já adquirido no processo de otimização, quando verificamos que as soluções mais sombreadas obtiveram maior porcentagem de pontos entre $300 \mathrm{e}$ 750 lux. Contudo, sem a simulação anual e apenas com os três objetivos de desempenho, não teríamos informações suficientes para realizar uma escolha de projeto bem fundamentada. A falta de clareza ocorre, sobretudo, nos casos com desempenho intermediário. Até que ponto seria interessante aumentar um pouco a incidência para ter maiores valores de iluminância?

\section{Considerações finais}

Este trabalho descreveu a elaboração de modelo paramétrico de investigação do desempenho de proteções solares em fases iniciais de projeto considerando dois critérios até certo ponto conflitantes: sombreamento e aproveitamento da iluminação natural. A otimização aplica algoritmo genético, no qual as variáveis manipuláveis são tratadas como genes, que são transmitidos através das gerações.

O modelo geométrico é composto por um ambiente com abertura externa e possibilidade de configuração de obstrução frontal. Embora a modelagem do contexto externo possa apresentar significativas diferenças em comparação com um ambiente urbano real, algum nível de simplificação geométrica é necessário para manter o modelo completamente paramétrico. Situações urbanas mais complexas poderiam ser modeladas de forma tradicional (não paramétrica) a depender das circunstâncias de projeto.

A facilidade de uso da ferramenta foi uma das premissas do processo de elaboração. Assim, todas as configurações geométricas podem ser feitas no ambiente do Grasshopper, sem a necessidade de conhecimentos de modelagem. Para tornar o uso mais intuitivo, a seleção de propriedades superficiais dos materiais é feita através de cores.

Embora a ferramenta possa ser utilizada com manipulações manuais das variáveis por usuários que não dominam a ferramenta, para o aproveitamento de todos os recursos de otimização, é necessário ter conhecimento sobre o funcionamento de alguns componentes do Grasshopper e alguma prática no uso do Octopus.

Após a finalização do modelo, foram definidos os tipos de simulação e possíveis objetivos para otimização. Ao todo, pode-se realizar até quatro tipos de simulação. A partir dos resultados, foram também produzidos os quatro valores numéricos que podem ser usados como critérios de desempenho. A escolha dos objetivos do processo evolutivo tem grande relação com as características das soluções produzidas e com o desempenho. Consideramos que a adoção das iluminâncias médias como terceiro objetivo de desempenho permite boa diferenciação entre os casos que têm bom desempenho nos outros dois critérios (baixa incidência de radiação e alta porcentagem de pontos entre 300 e 750 lux). O uso da uniformidade como terceiro objetivo dificultaria essa distinção, pois os casos de maior uniformidade seriam também os de menor incidência de radiação. Vale ressaltar, contudo, que os objetivos adotados abordam tão somente aspectos quantitativos da iluminação natural. Em desenvolvimentos futuros, poderiam ser realizados testes com outra combinação de objetivos ou até avaliada a viabilidade de adoção de outras grandezas relacionadas à qualidade da iluminação.

O uso de algoritmo genético, embora apresente limitações para simulações mais demoradas (e, consequentemente, cálculos mais sofisticados), apresentou-se válido para auxiliar na compreensão sobre a relação entre a solução de proteção solar e seu desempenho na redução da radiação direta e aproveitamento da iluminação natural. A adoção dos três objetivos que resultam de simulações rápidas permitiu a simulação de 35 gerações de casos, dentre os quais foram selecionados seis para avaliações mais aprofundadas. Os casos simulados podem ser visualizados em gráfico 3d, cujos eixos representam o quão próximo os casos estão de cumprir cada objetivo definido. Desse modo, é fácil a identificação do comportamento das distintas áreas do gráfico e a associação que se pode fazer entre os critérios de desempenho e as soluções obtidas pode ter potencial didático. Entretanto, para fundamentar uma escolha de projeto, os objetivos de desempenho não são totalmente suficientes pela falta de clareza da importância relativa entre as variáveis.

Para embasar o processo decisório, a última etapa de avaliação consiste em simulação anual de iluminação natural. De acordo com os resultados, na situação simulada com abertura oeste não foi encontrado conflito entre os critérios de iluminação e sombreamento. Pelo contrário, as soluções com menor incidência de radiação direta obtiveram maior porcentagem de horas nos intervalos de 100 a 2.000 lux e de 300 a 750 lux. Algumas variáveis fixas do modelo contribuem para uma grande incidência de luz natural na área próxima da janela. A área da abertura (1,7 m x 1,5 m) é considerável em relação à área do ambiente, o uso de vidros claros tem alta transmissão de luz e as proteções solares são brancas. Somado a esses fatores, a característica 
da fachada oeste de envolver incidência direta de radiação no período da tarde durante todo o ano contribui para que o excesso de luz seja o maior problema.

A aplicabilidade prática da ferramenta em situações de projeto obviamente depende não somente da disponibilidade de tempo para simular o máximo possível de gerações, mas do interesse do arquiteto em buscar níveis mais elevados de desempenho. O uso do programa requer conhecimento técnico sobre os fenômenos e grandezas envolvidos - além de certo domínio da ferramenta.

Vale também destacar outro elemento do processo de otimização que é pouco lembrado: a capacidade que temos, como projetistas, de aprender com essas simulações. Normalmente, procedimentos de otimização são associados à obtenção de uma solução final, com o melhor desempenho possível. Para garantir isso, seria necessária a convergência do modelo - o que pode necessitar de dezenas de gerações a mais. O uso de avaliações multicritério em contexto prático não necessariamente deve buscar uma solução final, mas funcionar como meio de aprendizado para que, ao identificar padrões, possamos melhorar ainda mais os casos selecionados com rápidas iterações manuais. Procedimentos dessa natureza, que combinam o considerável poder de análise das ferramentas com a capacidade de síntese do projetista (VENÂNCIO, 2012), são perfeitamente condizentes com a prática de projeto.

Por fim, destacamos que os resultados encontrados de convergência entre sombreamento e iluminação não necessariamente se aplicam a outros cenários e tipos de proteções solares - o que reforça a necessidade de diversificar os estudos para uma melhor compreensão sobre o peso e a importância das variáveis envolvidas.

\section{Referências}

ASSOCIAÇÃO BRASILEIRA DE NORMAS TÉCNICAS. NBR ISO/CIE 8995-1: iluminação de ambientes de trabalho. Rio de Janeiro, 2013.

BAY, J.-H. Cognitive biases in design: the case of tropical architecture. Delft, 2001. PhD - TU Delft, Delft, 2001.

DE WILDE, P. Computational support for the selection of energy saving building components. Delft, 2004. - PhD, Delft University of Technology, Delft, 2004.

DUBOIS, M.-C. Shading devices and daylight quality: an evaluation based on simple performance indicators. Lighting Research \& Technology, v. 35, n. 1, p. 61-76, 2003.

GERO, J. S.; KAZAKOV, V. A genetic engineering approach to genetic algorithms. Evolutionary Computation, v. 9, n. 1, p. 71-92, 2001.

HO, M.-C. et al. Optimal sun-shading design for enhanced daylight illumination of subtropical classrooms. Energy and Buildings, v. 40, 2008.

KIRIMTAT, A. et al. Multi-objective optimization for shading devices in buildings by using evolutionary algorithms. In: IEEE CONGRESS ON EVOLUTIONARY COMPUTATION, Vancouver, 2016.

Proceedings [...] Vancouver, 2016.

MARDALJEVIC, J. et al. Daylighting metrics: is there a relation between useful daylight illuminance and daylight glare probability? In: BUILDING SIMULATION, Leicestershire, 2012. Proceedings [...]

Leicestershire, 2012.

MARDALJEVIC, J. Examples of climate-based daylight modelling. In: CIBSE NATIONAL

CONFERENCE, Citeseer, 2006. Proceedings [...] Citeseer, 2006.

NABIL, A.; MARDALJEVIC, J. Useful daylight illuminances: a replacement for daylight factors. Energy and Buildings, v. 38, 2006.

O'CONNOR, J. et al. Tips for daylighting with windows: the integrated approach. Berkeley: Lawrence Berkeley National Laboratory, 1997.

PEDRINI, A. Integration of low energy strategies to the early stages of design process of office buildings in warm climate. Brisbane, 2003. PhD - Department of Architecture, University of Queensland, Brisbane, 2003.

REINHART, C. F.; MARDALJEVIC, J.; ROGERS, Z. Dynamic daylight performance metrics for sustainable building design. Leukos, v. 3, n. 1, p. 7-31, 2006. 
SINGH, V.; GU, N. Towards an integrated generative design framework. Design Studies, v. 33, n. 2, p. 185-207, 2012.

TORRES, S. L.; SAKAMOTO, Y. Facade design optimization for daylight with a simple genetic algorithm. In: BUILDING SIMULATION, Pequim, 2007. Proceedings [...] Pequim, 2007.

VENÂNCIO, R. Modos projetuais de simulação: uso de ferramentas de simulação térmica no processo projetual de arquitetura. Natal, 2012. Tese (Doutorado em Engenharia Civil) - Programa de Pós-Graduação em Arquitetura e Urbanismo, Universidade Federal do Rio Grande do Norte, Natal, 2012.

VIERLINGER, R. Multi objective design interface. Viena, 2013. Dissertação (Mestrado em Engenharia) Institut für Hochbau und Technologie, Viena, 2013.

Unidade Acadêmica de Engenharia Civil, Curso de Arquitetura e Urbanismo | Universidade Federal de Campina Grande | Rua Aprígio Veloso, 882, Universitário | Campina Grande - PB - Brasil | CEP 58429-900 | Tel.: (83) 2101-1264 | E-mail: raoni_vsl@yahoo.com.br

\section{Ambiente Construído}

Revista da Associação Nacional de Tecnologia do Ambiente Construído

Av. Osvaldo Aranha, $99-3^{\circ}$ andar, Centro

Porto Alegre - RS - Brasil CEP 90035-190

Telefone: +55 (51) 3308-4084

Fax: +55 (51) 3308-4054

www.seer.ufrgs.br/ambienteconstruido

E-mail: ambienteconstruido@ufrgs.br 